\title{
INSTRUCTING JUDGES: ETHICAL EXPERIENCE AND EDUCATIONAL TECHNIQUE
}

\author{
CyNTHIA GRaY* and Frances Kahn Zemans**
}

\section{INTRODUCTION}

To protect their rights and privileges, citizens in a democracy entrust judges with considerable authority and discretion and are entitled, therefore, to judges who are competent, independent, and honorable. Judges' actions must inspire confidence in the impartiality and integrity of their own decisions and the judiciary as a whole. Thus, judges are held to the highest standards of professional behavior. Off the bench as well, judges must conduct themselves with honesty and propriety and avoid behavior that demeans their office. In recognition of the importance of high standards of judicial behavior, all states and the federal government have adopted a code of judicial conduct.

Yet despite the importance of judicial conduct to the legitimacy of the third branch of government, there are virtually no pre-bench opportunities for judges to learn the limits of appropriate behavior. This neglect begins with our system of legal education. Judges essentially receive their formal education about conduct and ethics while they are in law school. As this symposium makes clear, a wide range of scholars and practitioners question the effectiveness of that education. Furthermore, even if legal ethics education were dramatically enhanced, the rules of conduct for impartial arbiters must necessarily differ significantly from those designed for advocates in an adversary system. Thus, even if law schools did a superb job of teaching legal ethics, that would not suffice as a grounding for future judges.

In law school, there is little scholarly research and even less teaching about judicial conduct and ethics. Despite the considerable body of law concerning judicial ethics, only one law school in the nation (DePaul University College of Law) offers a full course in the subject, and very few courses on attorneys' professional responsibility cover judicial ethics. In fact, most professional responsibility textbooks do not discuss judicial conduct at all, and those that do merely skim the surface of the subject in a short chapter that typically is placed at the end of the book.

Not surprisingly, therefore, many judges find themselves unprepared for the ethical dilemmas they face when they make the transition from partisan

Copyright (C) 1996 by Law and Contemporary Problems

- Director, American Judicature Society Center for Judicial Conduct Organizations.

- Executive Vice President and Director, American Judicature Society. 
advocate to neutral arbiter and, though well-intentioned, may run afoul of the code of judicial conduct. In addition, the code is, in many respects, written in general language that leaves judges uncertain of the appropriate behavior under specific circumstances. For example, the code requires judges to avoid not only actual impropriety, but also the appearance of impropriety. Absent ethics education, judges are left to their own devices to understand this requirement and other requirements under the code and a vast body of relevant case law that can be confusing and contradictory. Although all states and federal circuits have annual judicial conferences and some have additional programs such as training for new judges and continuing judicial education, ethics has been taught to judges in many jurisdictions only sporadically or not at all.

Recently, many states have begun to require judges to take three hours of ethics training every two years, and judicial educators are beginning to appreciate the need to provide ethical training for judges. ${ }^{1}$ However, they are hampered in their efforts to do so by a lack of teaching materials and a lack of persons with the knowledge and expertise to teach the courses. At the time a judicial ethics curriculum project was proposed to the W.M. Keck Foundation, the president of the National Association of State Judicial Educators reported that states had no curricular materials to teach judicial ethics other than two half-hour videotapes produced by the American Judicature Society ("AJS")and several AJS publications.

Despite the recent state requirements of judicial training, decreasing public budgets have restricted state resources and have resulted in a substantial increase in requests for AJS staff to provide educational programming. The Keck Judicial Conduct and Ethics Curriculum, which is the subject of this article, grew out of this demand.

II

\section{THE KeCK JUdicIAL CONDUCT AND ETHICS CURRICULUM}

\section{A. The Design of the Curriculum}

To fill the need for judicial educational materials in a cost-effective and selfsustaining way, and with funding provided by the Keck Foundation, AJS developed a nine-topic curriculum for judicial educators to use to teach judicial ethics to both state and federal judges at programs for new judges, continuing judicial education courses, or judicial conferences. The curriculum covers the following nine topics:

1 In some states, the judicial educator is a professional on the court staff whose primary or sole responsibility is conducting education programs for judges; a few states have more than one person. In other states, the role of judicial educator is filled by a judicial education committee comprised of several judges and authorized by the state supreme court. 
(1) the exercise of legal discretion-the line between judicial independence and abuse of authority, maintaining competence in the law, and abuse of the contempt power;

(2) the exercise of administrative responsibilities-neglect and delay, misuse of court personnel and facilities, disciplinary responsibilities, nepotism, and ethical standards for court employees;

(3) courtroom demeanor-treatment of attorneys, parties, witnesses, court personnel, and spectators;

(4) disqualification-bias and prejudice, family, social, and business relationships, and financial and property interests;

(5) ex parte communications-defining ex parte communications, exceptions to the prohibition on ex parte communications, and remedies for ex parte communications;

(6) off-the-bench speech-speaking, writing, and teaching, maintaining impartiality, and compensation;

(7) off-the-bench association-membership in political or ideological organizations, membership in private clubs with discriminatory policies, and associating with attorneys;

(8) business activities-investments, family businesses, other incomeproducing activities, service on boards of directors, and the practice of law; and

(9) civic and charitable activities-membership on boards of directors, fund-raising, and service for legal, educational, and other organizations.

The curriculum is based principally on the national body of law arising under the Model Code of Judicial Conduct, which was promulgated in 1972 by the American Bar Association ("ABA"). The curriculum also discusses the ABA's 1990 Model Code of Judicial Conduct, which retained the basic standards of the 1972 Code but made numerous changes. In considering the 1990 Model Code, many states have made significant changes, in part, to reflect specific state case law. Forty-eight states, the District of Columbia, and the United States Judicial Conference have adopted codes of conduct based on either the 1972 or 1990 Model Codes. Montana and Wisconsin have codes of judicial ethics that are not based on either model code, although many of the standards are similar. Thus, both state and federal judges are subject to virtually the same rules of judicial conduct.

The curriculum covers judicial conduct both on and off the bench. It emphasizes that judges are required to avoid not only actual impropriety but also the appearance of impropriety, and, therefore, that good intentions are not enough. The curriculum trains judges to be sensitive to situations that may ostensibly be innocent but may create a bad impression or present the potential to develop into a code violation.

To enhance the flexibility of the curriculum, each of the nine topics is covered in a self-contained module. Depending on time and budget limitations and on each topic's interest to the particular state's or federal circuit's judiciary, 
a judicial educator can design a training session lasting from one or more hours on a single topic to a presentation of the entire curriculum in a special program. By using one or two modules at annual judicial conferences, for example, the entire curriculum can be presented over several years.

The curriculum package includes a primer that is distributed to judges who participate in the program to provide background information on the course and to serve as a useful reference for the future. The primer is comprised of an outline that introduces the general principles and rules that govern judicial conduct in each topic area, with citations to the relevant portions of the governing code of judicial conduct, summaries of or citations to key cases decided by courts or judicial conduct commissions entrusted with the responsibility of enforcing the standards, summaries of advisory opinions issued by state ethics committees, and a list of suggestions for further reading.

AJS also prepared an instructors' manual for use with the primer. For each topic, the manual contains additional background material, suggested questions to stimulate group discussion, hypothetical situations, and descriptions of adult education techniques that can be used to present the curriculum.

\section{B. Presenting the Curriculum}

From March through September of 1992, AJS tested the draft curriculum by teaching one or more of the nine topics at several states' and federal circuits' judicial conferences or judicial education programs. AJS staff members used lectures and a variety of proven adult education techniques such as Socratic dialogues, small group discussions, and scenarios, with an emphasis on interactive class discussion. ${ }^{2}$ Where appropriate, staff members also made use of the videotape series Judicial Ethics and the Administration of Justice that AJS produced in 1990. On the tapes, professional actors portray judges, and a panel of experts discusses the ethics questions raised in the scenarios. The two tapes are one-half hour each and are accompanied by an instructors' manual and selfstudy guide. These tapes are a helpful supplement to the curriculum and are particularly effective in stimulating discussion among the judges participating in the program.

At each presentation, the judges were asked to complete a questionnaire to evaluate both the substance and the methods of the presentation. In September 1992, AJS revised the curriculum materials in response to the judges' comments and suggestions.

In October 1992, AJS showcased the curriculum to the National Association of State Judicial Educators ("NASJE"), which was founded in 1975 as an association of professionals responsible for planning and executing continuing

2 For example, in one case, an AJS staff member began with a lecture introducing the established law on ex parte communications, then provided the judges with a hypothetical (based on one or more actual situations in which judges have been charged with violating the rules) and divided them into small groups to discuss how a judge should handle the situation. The AJS staff member then led a discussion by the whole group. 
judicial education programs. With the strong support of the then-president of NASJE (Jerry K. Beatty), AJS demonstrated the curriculum the day before NASJE's annual meeting, which enabled AJS to present the curriculum costeffectively to the maximum number of state judicial educators. In addition to judicial educators, AJS invited judges designated by the chief justice of each state and the chief judge of each federal circuit. AJS made a particular effort to ensure participation by those judges who are influential in determining the content of local judicial education programs.

At the NASJE demonstration, AJS presented six of the topics from the curriculum using a variety of adult education techniques. Judicial discretion and disqualification were presented using lecture and Socratic dialogue; the participants were divided into small groups for a discussion of courtroom demeanor; there was a panel discussion of judges' free speech rights; and participants took a self-test on civic and charitable activities and social activities, followed by a discussion of the test questions.

After the NASJE presentation, AJS made final revisions to the primer and the instructors' manual based on the educators' evaluations and the AJS staff experience in previously presenting the curriculum at judicial education programs. The revised primer and the instructors' manual were then sent to the judicial educator and chief justice in every state and the chief judge of each federal circuit for use in their judicial education programs.

\section{Use of the Curriculum}

Eighteen months after distributing the curriculum, AJS surveyed the fifty state judicial educators to determine to what extent the curriculum was being used and to solicit suggestions for possible revisions. More than a third of the respondents had already used the curriculum, and another third had definite plans to use it in the near future. Many of the states had used it multiple times and planned to continue using it.

Approximately 1,750 judges had been taught judicial ethics with the materials provided, and approximately the same number were expected to be presented parts of the curriculum in the near future. The majority of these judges had been exposed to the curriculum in continuing judicial education programs, but it had also been presented in new judge training programs. Part of the curriculum had also been presented to an audience composed largely of practicing attorneys. While the curriculum was not planned for this use, several of the topics-for example, ex parte communications, disqualification, and courtroom demeanor-are certainly applicable to them and therefore can be useful in continuing legal education as well.

The survey results also indicate that the entire curriculum is being used. All topics have been presented at least once. The modules on ex parte communications, disqualification, courtroom demeanor, and civic and charitable activities were presented most frequently, which verifies our impression that these are areas in which judges are always seeking additional guidance. 
The curriculum was designed so that it could be used in a variety of ways, and the survey results confirm that the study materials are being used as the basis for materials being handed out to participants, the instructor's materials are being used to provide additional background for faculty, and the various learning activities are being used to present the issues. The study materials have also been found to be readily adaptable to the law of the individual states.

\section{III}

\section{CONCLUSION: LOOKING TO THE FUTURE}

The success of the curriculum confirms the need for educational materials on judicial conduct and ethics and suggests that further efforts should be explored. One such effort is further modifying the curriculum to respond to valuable suggestions and to cover new topics. For example, the curriculum could be modified to respond to the following suggestions by survey participants: (1) incorporate new court rulings; (2) expand the coverage of gender and race issues; and (3) add political activity of judges as a topic. Increasing interest in abuses of power by government officials also suggests inclusion of a unit on misuse of the judicial office, which would consider conduct such as doing favors for friends, asking for favors from other officials, testifying as a witness, and making personal recommendations.

The curriculum could also be adapted to address the needs of part-time judges. More than half of the states have judges who serve only part-time. Simultaneously practicing law and administering justice on the bench creates special ethical difficulties. Many of the advisory opinions issued by state judicial ethics advisory committees are in response to requests for guidance from parttime judges, particularly in the areas of disqualification and outside business activities. Although some provisions of the code of judicial conduct are waived for part-time judges (most obviously the prohibition on practicing law), most of the code does apply to them, and they are required to uphold the integrity, impartiality, and independence of the judiciary full-time while sitting on the bench only part-time.

The curriculum could also be extremely useful as a tool for training members of state judicial conduct organizations, especially the public members who, in all likelihood, have had no legal ethics training. Because such organizations are under the immediate pressure to decide a specific complaint against a judge as it arises, their members usually do not have an opportunity to get an overview of judicial ethics and discipline. The curriculum could provide this general guidance.

Finally, to encourage law schools to teach judicial ethics, AJS would like to conduct a summer seminar for law professors based on the curriculum. Promoting the inclusion of judicial ethics in the law school curriculum would emphasize for future lawyers and judges the role that both lawyers and judges play in preserving the independence and impartiality of the judicial system. The topic of judicial ethics could be included through a seminar on judicial ethics, 
a judicial ethics component in a course on professional ethics, or by integrating judicial ethics issues into other subjects in the curriculum. ${ }^{3}$ As law professors and deans debate the best way to incorporate legal ethics into the law school curriculum, the AJS curriculum on judicial conduct and ethics offers an additional resource and approach.

3 For example, the First Amendment issues raised by restrictions on judicial speech would be an ideal subject to introduce in a constitutional law course. 
